\title{
Why the Microlevel Determines the Future of the Social Market Economy?
}

Elmar Nass*

Wilhelm Loehe University of Applied Sciences, Fürth, Germany

Received November 27 2017; Accepted December 182017

Abstract: The main concern of this paper was to identify the homogeneity between the micro- and macro-level of social market economy. It shows the transfer of the normative main idea of the social market economy to concepts of leadership ethics with which it is compatible concerning the basic ideas. They will be identified as leadership models of the social market economy and therefore differentiated from those that contradict these ideas. To this end, an attempt will first be made to recall the normative foundations of the social market economy. Leadership will be henceforth identified as an application area of this value basis on the microlevel. Subsequently, the systematic approach will be traced for a transfer from the macro-level to the microlevel.

Keywords: Leadership ethics $•$ Humanity $・$ Macro-micro-model $\bullet$ Leadership culture

\section{Introduction}

The sustainability of the social market economy does not depend primarily on theoretical debates about any practical rules. The German ordomodel of the social market economy becomes apparent a) in its normative main idea and b) in the way it is realized in the practice of economy. The main concern of this paper was to identify such homogeneity in the range of the microlevel of management culture in enterprises. In this respect, it follows well-known representatives such as Ingo Pies and Peter Ulrich, who brought this claim up for discussion - along with their own integrative perspective - to orientate management culture at the microlevel toward normative basic ideas of the (social) market economy. ${ }^{1}$

The social market economy is more than the basic idea of an economic system. In the spirit of its founding

1 Cf. Pies/Beckmannn/Hieschler (2011) and Thielemann/Ulrich (2009). fathers, it is also a social peace formula, a comprehensive cultural program (the idea of the so-called "irenicism"). This applies not exclusively, but in particular for all spheres of the economy. Therefore, it primarily wants to shape the self-conception of the company and managers together with the company's and management's culture of market players, besides the fact that its main function is an economic system with its rules and principles. Therefore, the micro-, meso-, and macro-levels can be infused by the value idea of the social market economy and contribute constructively to their further development. In this way, it makes it possible to avoid the model being undermined by a disavowing practice. The following sections show the transfer of the normative main idea of the social market economy to such concepts of leadership ethics with which it is compatible concerning the basic ideas. They will be identified as leadership models of the social market economy and therefore differentiated from those that contradict these ideas.

To this end, an attempt will first be made to recall the normative foundations of the social market economy. 
Leadership will henceforth be identified as an application area of this value basis on the microlevel. Subsequently, the system will be traced for a transfer from the macro-level to the microlevel.

\section{Value basis of the social market economy}

Social market economy is essentially a market whose allocation results are put into service for a normative humanitarian ideology. Market economy and humanity are in tight interplay with each other. The outlined normative frame of the market is objectively justified in the sense of Walter Eucken also with a Kantian rational idea, in the works of Alfred Müller-Armack, Alexander Rüstow, Wolfgang Röpke et al., with the retrospective dependence on a Christian godliness of man.

To quote Ernst-W. Bockenförde, it is also semantically rich in content, an axiomatic adjudication of eternity. This unconditionality eludes individualistic or collectivist considerations of utility, extremist arbitrary definitions of humanity, and processes of discourse in which one can broker human rights or dignity of man openly and in an unbiased way. The normative framework of the market in this model establishes the objective rights and obligations of every human. Human here means that everyone who is a child of man without exception. Such a humanitarian idea establishes the values of social market freedom, social justice, and social harmony. Freedom is to be understood positively in terms of the idea of an empowering idea, because objectivized universal rights for the unfolding of humanity must also be derived from the absoluteness of humanity. This is reflected in the cohesion of solidarity and subsidiarity as social justice, according to which, the unconditional rights of the needier which correspond to the unconditional duty of the capable to help - in terms of requirements and support. Social harmony is in accordance with Müller-Armack's demands; the aim of this system must always be a peace-making effect, ideally with the affective cooperation of all the individuals concerned.

\section{Leadership as part of social culture}

Leadership in an enterprise on the market is central here, including both profit and nonprofit organizations equally; even the public sector is addressed (particularly in saving banks, public hospitals, etc.). Therefore, the author asks: What does leadership in enterprises mean?
The conceptual difference between management and leadership is not distinct. For this reason, a weak distinction is suggested. First of all, let us concentrate on what both spheres have in common. Both management and leadership are about the effective impact of rules, individuals, and relationships in enterprises. Management is performed either correctly or wrongly, but not in a moral sense of right or wrong. This is a crucial difference. Rational solutions for temporally and substantially definable problems with the aid of proved techniques are central where management is concerned, whereas leadership cannot confine itself to technical knowledge already acquired. Leadership should also reduce insecurity and possibly fear of the led, and in the same way also confront them with their autonomy/responsibilities. It is characterized less by tangible solutions and more by the right questions. As Grint described it, "there is no 'right' or 'wrong' answers, but there are better or worse alternatives."2

Leadership in an enterprise not only is therefore the skilled application of learnt abilities to give people in the enterprise effective orientation but also takes moral concepts that complement the bare instrumentally measurable effectiveness of the orientation of the uncertain into consideration. This makes empirical validation difficult. Therefore, leadership - more than correctly learned management - has to include and explicitly address value questions for an effective influence on men and structures. "Leadership is a process of morality to the degree that leaders engage with followers on the basis of shared motives and values and goals". ${ }^{3}$ Ciulla argued along the same lines: "in order for the statement, 'She is a good leader' to be true, it must be true that she is effective and she is ethical." ${ }^{4}$ With such an understanding, the aim of good leadership is initially the coherence between the intended values and those lived in practice. A basic definition must be adhered to the following: leadership is the value-based, effective influence of rules, individuals, and relationships in an enterprise.

Leadership happens in enterprises everywhere where such influence takes place, no matter in which department or committee. It proceeds in horizontal and vertical relationships ${ }^{5}$ with formal executives and those who are guided influencing each other. ${ }^{6}$ In this way, even the employees being guided also lead not only by creative suggestions that might be successfully contributed but also by verbal and nonverbal reactions to the formal leader. It is typical for enterprises to have hierarchical

2 Grint (2008). Cf. ibid (p.15) and Heifetz (1994).

3 MacGregor Burns (2007, p.87).

4 Ciulla (2007, p.69).

5 Cf. Malik (2006, pp.50-52).

6 Cf. von Oelsnitz (2012, p.18) and Rohrhirsch (2013, p.73). 
roles with asymmetry of power. ${ }^{7}$ However, leadership is also an effective communication that happens not only hierarchically top down but also in the same way on the same level horizontally and hierarchically bottom up. By viewing in this light, those who are guided - seen hierarchically - can also lead the executive on a level above theirs. Leadership has a formative influence on culture. It refers not only to the impact relating to the behavior of other individuals but also to other aspects of company culture; therefore, it influences the actual practiced relationships that are expressed - for instance - in the company rules. ${ }^{8}$ Culture is important as the strong, latent, and often unconscious cultural forces determine behavior, thought patterns, and values - individual and collective. Company culture is crucial as cultural elements determine strategies, aims, and manner of functioning. ${ }^{9}$ According to Schein, company culture consists of visible and, to a much larger extent, mostly concealed spheres. It has a direct relationship with values, namely as an origin of the visible as well as an effective influencing factor on values. Melé and Cantón emphasized the fact: "Organizational culture is a composite of people's behaviours within the organization and in the underlying shared beliefs, meaning and values, the norms commonly applied and the practices carried out."10

Leadership culture means a value-based influence on a company and organizational culture with its transparent and concealed values. Agents of leadership are initially individuals who create, influence, and modify the culture. However, leadership happens through the effectiveness of rules on these agents. Even the company culture (as a whole) effectively shapes the individuals and is an agent itself as an abstract factor. In addition to the values set by the individual, this also includes a concept of a world view, for example, that of a Christian provider in the social market, and its consequences for internal rules and relationships.

Thus ideological values, rules, and individuals are the personal or apersonal "actors" of the management of the company. Just as with the social market economy as a basic concept of an economic order (macroperspective), characteristic spheres of leadership that take a normative idea into account in a practical way can now also be identified on a microlevel. For this purpose,

7 Cf. Ulrich (1999, p.230).

8 Cf. von Oelsnitz (2012, p.19). Culture is not identical to the rules defined in codes and guiding principles, as it is a lived reality. Cf. Noll (2002, p.131).

9 Cf. Schein (2003, p.29). Short reference to his three-level model that claims that we need to differentiate between invisible postulated basic assumptions, partly visibly values, and the concretely visible acts. For a short overview, cf. Hüster (2016, pp.21-28).

10 Melé/Cantón (2014, p.45).
Palazzo differentiated between the particular incentive structure, culture, and control and trust as well as structuring of decision-making. ${ }^{11}$

This systematic approach can now be continued in a three-tiered approach: effective influence of rules, individuals, and relationships, i.e., leadership, is essential significantly in the cultures of personnel planning, deployment, and development of communication (including hierarchy, power, and delegation) and motivation (including loyalty, identification, control, and incentives). These three relevant fields of application are given as an example in the following. Personnel planning, placement, and development affect the leadership culture enormously by, e.g., the choice of executives and other employees, by the team composition, and also by development and education programs or measures. Depending on the value basis, it is basically crucial to seek for other characters, other traits of people, and other team cultures. This has an immediate impact on the decisions of education and promotion, too.

- Communication and company culture that related to it, for example, hierarchy, power, and delegation culture, basically serve in the leadership culture either in fast decision-making or in a critical participation of as many employees as possible.

- A leadership culture stands out due to its understanding of achievement motivation. In which way are different cultures of trust justified and implemented? Which form of control is implemented, and why? In addition, how will this achievement motivation be influenced in a positive effective way: rather than by extrinsic incentives or by a culture of intrinsic motivation?

The following three ethical leadership applications have direct influence on the answer to those practical questions asked in the everyday life of companies: Which characteristics should a leader have ${ }^{12}$ Which employees should be hired? Which training measures should be encouraged?

Should leaders rely more on cooperative or topdown decisions? Control or trust? Rivalry or team? What should be favored - extrinsic financial incentives or intrinsic motivation due to discretion and identification? In the fields of application, the leadership culture, which prescribes leadership ethics as normative, becomes concrete.

11 Cf. Palazzo (2007, p.120).

$12 \mathrm{Kuhn} /$ Weibler (2012) criticized that especially machiavellists, narcissists, or psychopaths determine the race at the moment. 
These areas of practice cannot be discussed individually in this paper. Instead, we focus on a systematic model of normative ideas being offered by leadership ethics. This will be compared to the value basis of the social market economy. Therefore, we now need to identify the substance of leadership ethics.

\section{Leadership ethics}

Leadership, along with the culture of leading, is the universe of discourse of leadership theory and therefore also leadership ethics, which is a branch of leadership theory. Leadership theories, according to the standard leadership ethics textbook by Lang and Rybnikova, are systems of states about the phenomena of leadership and the leading itself that should describe and explain specific recent phenomena of leading. ${ }^{13}$ This includes explicitly normative phenomena, because - as we have seen - leadership has always something to do with values. Therefore, if we analyze the influence of specific styles of leadership and possible traits of executives on the motivation of employees, it is always part of leadership theory.

However, the bare descriptive analysis of the normative is not yet an ethical, but rather a theoretical evaluation of the values in practice, which contributes to the assessment criterion of responsibility. Its subject is leadership culture in all areas of the company, departments, and hierarchical levels as a responsible influence of employee's behavior. ${ }^{14}$ It addresses the normative basis for an intended influence of behavior. ${ }^{15}$ It offers criticism of a practiced leadership culture, not only in the sense of an assessment of coherence but also of evaluation of the basic values being (ir)responsible in the sense of morally good or bad. ${ }^{16}$ Leadership ethics does not content itself with the description and the explanation of phenomena but reflects the leadership culture in a company based on its own value system. It is therefore not a positive discipline that analyzes normative processes in a value-neutral or purely quantitative manner and then systematically composes them in an ethical decision theory.

As a normative theory, it instead asks for normative evaluations according to the moral foundations in leadership and their effectiveness, whereby the general, nonethical leadership theory also comes into play in the evaluation of effectiveness. It can be held for the conceptual sharpening of leadership ethics: leadership ethics is a guiding theory that explicitly evaluates leadership practice with a transparent value system. It theoretically creates a normative system with transparent values. The values are then themselves the basis for being able to evaluate leadership practice normatively. Thus, the importance of normativity in leadership ethics can be illustrated in terms of leadership and management (Table 1).

Thus, a leadership ethical model must provide leadership on its own value base for its application area. Its basic normative idea can now be reconciled with the value basis of the social market economy, which has a primary focus on only one other area of application.

\section{Leadership ethics of the social market economy}

Thus, the essence of leadership ethics can be concretized in terms of its compatibility with the fundamental values of social market economy. A leadership ethics of the social market economy (LESME) must be based on a transparent value base, and its ethics must be based on its normative assessment of the leadership culture, above all the ratio of profitability and humanity without exploiting or substituting one of the objectives. The other essential normative principles and principles outlined earlier must also be taken into account. ${ }^{17}$

The purported analogy between the economic system (macro-level) and ethical leadership level is

\begin{tabular}{c|ccc}
\hline & Management & Leadership & Leadership ethics \\
\hline Task & $\begin{array}{c}\text { Giving practical orientation as a } \\
\text { learned skill }\end{array}$ & $\begin{array}{c}\text { Giving practical orientation also } \\
\text { with values }\end{array}$ & Normative evaluation of leadership \\
Evaluation & "Right" or "wrong" in the sense of & Effective and morally "right" or & Ethically "good" or "bad": questioning the lived values \\
& effectiveness & "wrong" in the sense of values & with the help of a transparent normative system \\
& & Effectiveness and practically & Theoretically normative coherence \\
& & normative coherence & \\
\hline
\end{tabular}

Table 1. Management-leading-leadership.

13 Cf. Lang/Rybnikova (2014, p.27).

14 Cf. Kuhn/Weibler (2012, p.27).

15 Cf. von Oelsnitz (2012, p.8) and Ulrich (1999, p.230).

16 Cf. Schwartz (2016).
$17 \mathrm{Cf}$. for a further refined examination in replicable steps with the help of a guideline (Nass 2017). 
underpinned graphically (Figure 1). Therefore, it is noted that the scope of leadership defines perspectives (rules, individuals, relationships) of the condition of the two basic aims: economy and humanity. By analogy to a macroperspective of the social market economy, a system of leadership ethics can be identified. Therefore, one can identify characteristic spheres such as personal work, communication, and motivation for the field of leadershiprather than that of organization. Thus, the simple analogy between the macro- and microlevel is as follows:

A) Profitability targets: principle of efficiency avoids wastage

B) Henceforth, the goal of humanity applies in the field of leadership from these three perspectives:

1) Rules for personal work, communication, motivation

2) Individuals:

a) self-concept of the individuals

b) form of rules

3) Relationships (in the sense of the irenic idea of peace): horizontal and vertical social culture among themselves and their interaction with the rules (e.g., the culture of loyalty)

It is easy to infer from this analogy that LESME has to evaluate how profitability and objective orientation on humanity are understood as an independent end in itself and how they are correlated with each other, taking positive freedom, equal social principles, and affective coexistence for the field of leadership into account. This central question is discussed in the following sections. Of course, it is provided that neither of the two aims will be sacrificed for the other, because it would mean that the necessary ratio determination of the relevant basic social market values would be entirely excluded. If one perspective of leadership is overlooked, the result would be that an implementation of this leadership culture would lead either to economic depersonalization or to utopian de-profitability of entrepreneurial acts in the long term. Both efficiency and orientation on humanity have to be accepted as noninterchangeable goals of leadership when we talk about LESME. Otherwise, such attribution would be wrong. Just as the relationship is defined in concrete terms by the respective value base to which objective greater weight is attributed, different leadership ethical paradigms and approaches can again be distinguished within this sense horizon. Depending on the consistency with the basic values, the respective proximity or distance can then be further differentiated. However, the focus is on the basic question of the cooperation of the two non-substitutable goals of profitability in the market and humanity with an objective understanding of positive freedom and the consequences of relationships in a company.

Therefore, we can differentiate between a nonethical leadership theory and leadership ethics in a broader sense (ibs) and leadership ethics in a narrower sense (ins), which corresponds to the normative ideas of the social market economy (Table 2).

We have to differentiate between leadership ethics (ibs) - which is not meant (ins) because of its instrumentalization of the social aim - between

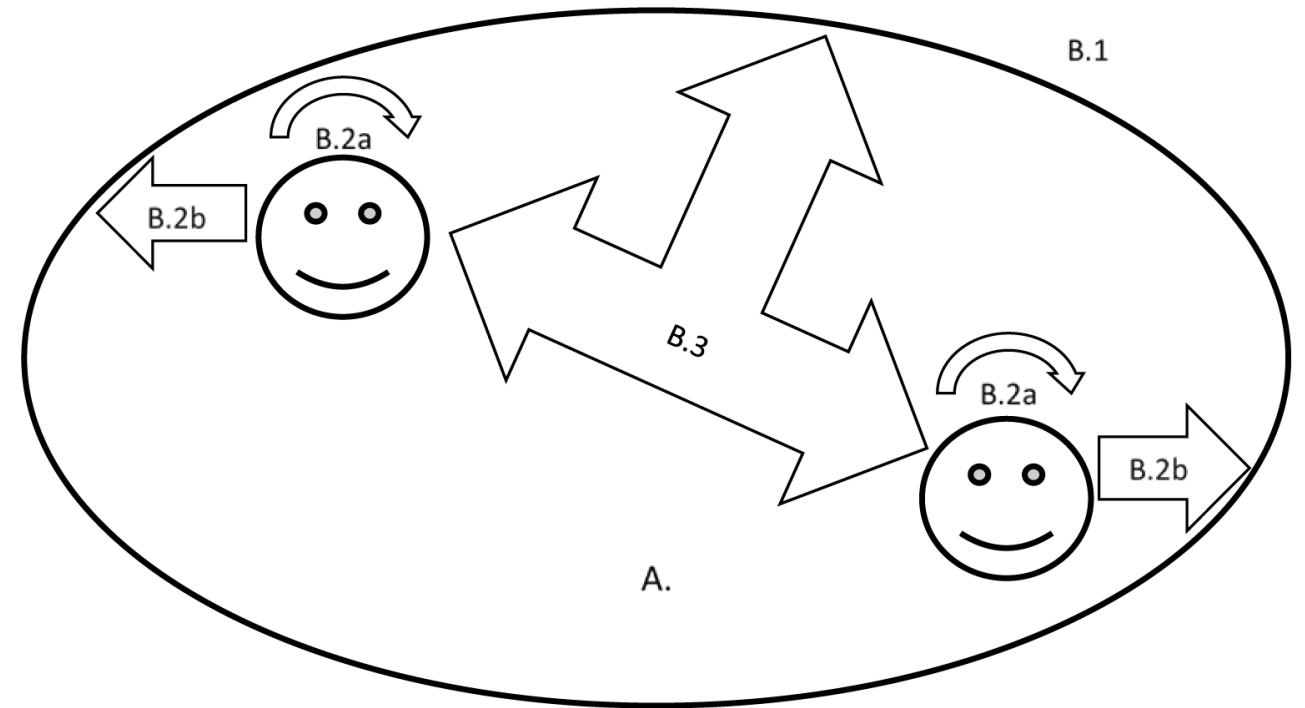

Figure 1. Values of the social market economy for the microlevel. 


\begin{tabular}{c|cc}
\hline $\begin{array}{c}\text { Nonethical } \\
\text { leadership theory }\end{array}$ & In a broader sense (ibs) & Leadership ethics \\
\cline { 2 - 3 } & $\begin{array}{c}\text { Normative evaluation of the culture } \\
\text { of leadership }\end{array}$ & $\begin{array}{c}\text { Normative evaluation of the culture of leadership considering the dualism of } \\
\text { goals: profitability/humanity, positive freedom, and social peace (irenic idea) } \\
\text { in the lived relationship }\end{array}$ \\
\hline \hline $\begin{array}{c}\text { Positive description of the } \\
\text { culture of leadership }\end{array}$ & \begin{tabular}{c} 
In \\
\hline
\end{tabular}
\end{tabular}

Table 2. Leadership theory and leadership ethics.

- $\quad$ those that are limited to the characteristics of homo economicus $(\mathrm{HO})$ and

- those that understand human beings as dialogic beings with an egoistic and ethical rationality

LESME is, according to our understanding, leadership ethics (ins). Imperialistic approaches are counted among the first group. They understand entrepreneurial responsibility as a structured process for the optimization of organizations without the aspect of humanity as an end in itself. In doing so, it follows the logic of Gary Becker and, for example, the business consultant, McKinsey et al. They are leadership ethics (ibs) as they evaluate normative leadership culture based on values. Approaches of the second group of leadership ethics (ibs) see human beings as a dialogic being with an egoistic and a non-egoistic rationality. Maybe it is also about coming to maturity which is a humane aim. However, this goal is only secondary here, exchangeable, and subjected to the single dominant profitability aim, and therefore it is instrumentalized. ${ }^{18}$ For example, Bruno Frey had this opinion of the so-called bright side of leadership, according to which, morality is an economic success factor: the consideration of the employee's wishes leads to the creation of value via appreciation. ${ }^{19}$ Kets de Vries said that the understanding of employees is a strategy for success and that satisfaction is the way to better performance. ${ }^{20}$ If this absolute positive synthesis of humanity and efficiency is correct, the humane aim should never be sacrificed. But this is a dream, as the basic assumptions of normative efficiency of these theories are not evident at all. There is also a dark side of economically successful leadership that is orientated only on profitability. ${ }^{21}$ Regarding the instrumentalized leadership ethics (ibs), it is crucial to note that the consideration of human aims is only legitimate as long as it helps to achieve more profitability. Otherwise, it can or even must be rejected to achieve the only valid aim

18 Cf. Sims/Brinkmann (2003, p.243).

19 Cf. Frey et al. (2010, p.643).

20 Cf. Kets de Vries (2009).

21 Such approaches follow the logic of Machiavelli. Cf. Kellermann (2004, p.5). The orientation on success is here the only criterion for the differentiation between the presumably strong and weak leading. of economic net product with other means that are not humanity. The personal development of men is an exchangeable means to the end of efficiency in these models. Admittedly, the apparent results of this practical leadership that follows the leadership ethics (ibs) might be seen as positive at first glance; however, the thought-provoking relativization of the humanitarianism of human dignity for such approaches is the exclusion criterion of being a LESME. As an ethics of leadership, they can and should be duly discussed.

LESME needs to treat the value basis differently:

- Humanity is understood as a non-exploited and nonexchangeable means to an end. A crucial aim of leadership in LESME is always the personal development of every single person depending on fixed basic skills and variable traits (e.g., preferences, feelings, and holistic life contexts).

- $\quad$ Even the aim of profitability should not be exploited or substituted. As companies in the market economy compete with each other, both the leaders and the design of rules and strategies have to keep economic success in mind. Of course, it needs motivated and well-qualified employees. These employees should not have the goal of self-realization at the expense of the company; otherwise, it would be an invitation for moral hazard which would further weaken the potential to identification. If profitability is completely sacrificed for the supposed aim of humanity, the probability of the company disappearing from the market would be very high. Other players with their own leadership cultures would take these places, and the humane aim would be sacrificed in the market in the name of serving humanity. The marketability has to be secured to prevent that, too.

LESME requires the normative development of every employee in a company as an end in itself normatively next to an economic calculation owed to profitability. ${ }^{22}$

22 Jussen (2009) emphasized the "untouchable subject character of human" as protection "against tendencies of technocratic absolutization of functional and efficiency aspects in dealing with working people." 
Under this condition, we can now differentiate between alternative schools of LESME.

\section{Classification for an evaluation}

There is no one and only true leadership ethics in the social market economy, just as there is no one social market economy either. In fact, we have to show that approaches of LESME which might be competitive have all the basic values of the social market economy and are therefore fruitful for the microlevel. Accordingly, there are two steps necessary to monitor it: identification as LESME and subsequently as LESME assignment to one of the basic normative paradigms that use this condition. For both steps, the respective value base and the resulting response to the relationship between the two basic objectives must be introduced.

We have to presume basic ideas of humanity (concepts of man) and duty as well as ideas of social community in the company as a value basis of leadership ethics analogous to institutional ethics. The value basis is the soil that has to be transparent, where the fruits of practice can be measured normatively. It also answers the question of what the relationship between individuals and the team and also the company as a whole is basically like. Which development is paramount? In addition, which practiced spirit should be connected: rather an anonymous coexistence or a confrontation with competition, or an interaction of conscientiousness or even affection? Is it human centered enough if the individual is subordinated to the collective body in the team or in the company? Or is the team or the company understood as a sum of selfactualizing individuals? Or are there interactions? These and other ideas have to be accompanied by an ideological justification to be transparent and traceable in their justifications. This can be either normative, individualistic, Kantian, metaphysical, discourse ethics, or otherwise.

Based on these values, the relationship between the two basic values of economy and humanity has to be defined. Economy and heuristically or anthropologically justified humanity as contrary and therefore absolute set goals for good leadership and leadership culture may converge. However, neither of the two aims should be sacrificed in a cultural program and degenerate to a bare nominalism. The relevant models are located between two extreme poles. On the one hand, there is the selfinterest of the market with self-sufficient egoism as a "virtue" toward which heuristic economic models tend. If for economic reasons humanity is completely endogenized - as for example in economic imperialism - then the relevant theory would not be LESME. On the other hand, there is an equally inefficient and also unrealistic collective thought that wants to subject not only internal decision processes in the company but also the fundamental legitimacy of entrepreneurial acting. Profitability on the market can be jeopardized with a utopian view of selfless and moral individuals in the voluntary duty of the collective - as defined. This bias might be represented in some deontological or metaphysical approaches. These extreme models are not LESME either.

\section{Leadership ethical paradigms by comparison}

Having identified exclusion criteria for LESME - based on known organizational and economic ethical discussion - we now turn our focus to three paradigms. These paradigms claim prima facie to correspond to the normative ideas of the social market economy and therefore seem to be LESME. ${ }^{23}$

A first normative individualistic school takes a respective heuristic as a basis for the economic ethics of Karl Homann et al. and HO. From this, it follows that companies that act on the market have the idea of employees as human resources in the sense of efficiency. This orientation on efficiency faces a heuristically simplified perception that is still open for a more sophisticated humanity orientation as an end in itself. However, it is not compulsory. This is the criterion that decides whether it is LESME or not.

Alternatively, a complex, anthropologically based human nature can be postulated with the help of which human beings are seen as persons beyond the counterfactual $\mathrm{HO}$ heuristics. In addition to profitability, the leadership ethics should also help the personal development of employees as such ethical models are not wrapped up in endogenizing economics. We also have to think about the optimization of the development of human beings as persons, depending on fixed and variable traits. In the sense of humanity, it is the personal development in its complexity as a mean in itself that faces the goal of profitability. We need to make an economic ethical difference between the deontological approach with Kantian influence and metaphysical models. In addition, this always happens analogous to the essential chains of argumentation of the idea of the social market economy. An assignment to LESME is only successful if the principle of profitability is not endogenized by the collectivistic idea of humanity. In the following sections, for each of the three selected paradigms, one model is discussed exemplarily and it is examined in the sense of the system: ordonomics as a normative individualistic model, the classic Kantian

23 More paradigms are easily conceivable. 
as a deontological approach/model, and servant leadership as a metaphysical approach.

\section{Normative individualism: ordonomic approach}

Ingo Pies and his followers suggested a leadership ethics who thought consequently one step further of the economic ethical model of Karl Human et al., in the frame of a so-called ordonomic approach. ${ }^{24}$ Of course, the idea of $\mathrm{HO}$ as a heuristic as well as normative individualism is provided. ${ }^{25}$ The ordonomic approach is to be understood as a model that describes the logic of a free market order in business economics and, here specifically, leadership ethics: the term "ordonomics" is socio-theoretically found and generally developed as a rational choice analysis (of interdependences) between social structure and semantics. ${ }^{26}$ Therefore, ordonomic leadership ethics is explicitly a macro-micro-model that raises the claim to repeal the seeming trade-off of economy and ethics. Finally, management is characterized by the economic logic. It is only when leadership ethics is not perceived as a disruptive factor that it has the chance to be heard and to take effect in its context. Of course, the principle of profit maximization is initially set in such an approach. A LESME is presented in that line. The logic of market economy and leadership culture is made compatible according to the principle of profit. Market-orientated, economic, and ordonomic logic of leadership ethics are normally coherent and therefore need no translation in theory nor in practice. This would be associated with costs.

The responsibility profile in the ordonomic approach does not follow simple profit maximization. Since the basic "yes" to the profit principle is understood differently than by Friedman, for whom "the social responsibility of business is to increase its profits." ${ }^{27}$ The profit maximization here is still uncontested as a goal, but this principle should be connected inextricably with the actual corporate purpose of the company: the social responsibility of companies and also of good leadership should ultimately be the value added as common good, as efficiency wants to avoid the waste of resources. As the real institutions do not conform to this ideal, we have

24 This strong connection is emphasized by Pies/Beckmann/Hieschler (2011, p.34) with reference to Homann/Pies (1994).

25 This approach understands itself as a value-added heuristic, in which there is no place for complex conceptions of man. Cf. Pies/ Beckmann/Hieschler (2011, p.25).

26 Cf. Pies/Beckmann/Hieschler (2011, p.15 f).

27 Cf. Pies/Beckmann/Hieschler (2011, p.17) with reference to Friedman (1970). to distinguish clearly so as to not lose the real responsibility of the added value. Efficiency as value added is thus social responsibility of companies and leadership.

As a result, leadership is basically orientated on the principle of profit, which is consistent with the economic approach. This is combined with a postulated responsibility for the organization of rules to promote efficiency by moral-free actions of the players. Therefore, leaders should not just play the given game, which is based on the rules in a company (leadership culture) well, but should make the rules and therefore the game better: the ordonomic approach works systematically to enable managers so that the companies they lead learn to play the game better. ${ }^{28}$ The formation of market rules is not the task of the state alone - in contrast to Friedman, for example. Companies are co-responsible for improving the game in the sense of net product value. This makes company ethics possible. By analogy, the leaders in a company are not just mere recipients of established rules; rather, they are jointly responsible for actively shaping them. The institutional ethical focus is therefore accompanied by an individual ethical part of a responsible, even regulatory, design of rules that are morally good if they serve the end of added value. The logic of the $\mathrm{HO}$ is based on the rule design appropriate for the creation of value. Moral - thus understood - does not follow any logic of a philosophical ethics that imports noneconomic semantics, since it is completely bound to the aim of profitability. The consequences of changes in the rule system can only be re-allocative as they serve the preservation of market efficiency, but they may not be redistributive..$^{29}$

Such a moral as production factor ${ }^{30}$ wants to guarantee a win-win situation in the combination of economic and moral logic. This situation does not see both goals as orthogonal positions and therefore not as dualism or even as competitors. ${ }^{31}$ The principle of the added value by realization of profits is seen as the representation of human usefulness in terms of efficiency. Such an approach does not compete with the economic but with the humane aim - understood as added value. Consequently, it is not about improving leaders "to better humans. Instead it is about educating better managers." 32 In light of the above, from an ethical point of view, it is also necessary to warn against a

28 Cf. Pies/Beckman/Hieschler (2011, p.28); Cf. ibid (pp.16-17, p.20); Pies/Beckman/Hieschler (2012, p.331).

29 Cf. Pies/Beckmann/Hieschler (2011, p.21).

30 Cf. Pies/Beckmann/Hieschler (2011, p.18). Cf. ibid (p.19, 32, 1111).

31 Cf. for that schematics of Pies/Beckmann/Hischler (2011, p.30) as well as Pies/Beckman/Hieschler (2012, p.328).

32 Cf. Pies/Beckmann/Hieschler (2011, p.33) with reference to Boatright (1999). 
morality which is contrary to the principle of efficiency. Value creation in terms of efficiency is then identical in the market to human diligence/usefulness. To determine the relationship between the objectives, two competing interpretations of human dignity must be distinguished. In the context of market economy (and therefore in the field of practiced leadership), it is substituted by the efficiency goal. In this perspective, the ordonomic approach is a concept of leadership ethics (ibs), but not a LESME. However, if we look at the service characteristics of the economy to the creation of value, which as a result benefits real (not heuristically reduced) people, then a separate perspective of human usefulness comes at least indirectly into focus, which ultimately also affects leadership ethics (ins). In this respect, we can see the ordonomic approach as LESME.

In summary, the ordonomic approach consistently transfers the basic idea of market ethics to the management level with a macro-micro-perspective. The abolition of the value dualism - essential for LESME - by an economic normative absorption through the economic perspective creates a new dualism of the second degree, since leaders should be good mangers, but not good people. A congruence of the goals on the individual ethical level is not reached. A new leadership ethical dualism comes into the focus of discussion. For a clear allocation as LESME, the heterogeneous human aim would have to be coherently defined. However, this clarification is still missing in the approach.

\section{Deontology: Kantian approach}

A classical Kantian approach as an ideological basis for leadership ethics is presented by Bowie. The underlying values and the idea of the development of men as persons are justified transcendentally. It is logically the direct result of the categorical imperative by Kant to treat human beings not only as a means to an end but also always as ends in themselves at the same time. With this the exploitation of individuals for economic calculation is absolutely forbidden - in terms of the necessity of rational thinking. On the one hand, personality is realized in a negative freedom: it is a necessary condition for a culture of autonomous-personal freedom: is the unconditional obligation to guarantee an "ability to act independently of determination by alien causes." 33 Force and imposition are forbidden categorically. ${ }^{34}$ The Kantian personality realizes itself nevertheless not only in negative but

33 Bowie (1998, p.1085).

34 Cf. Korsgaard (1996, p.113). A compulsory redundancy is here legitimate as the employees embarked to this potential risk before, Cf. Bowie (1999, pp.48-53). also always in positive freedom: personal development as normative autonomy means the empowerment of employees "to be a law unto themselves." ${ }^{35}$ This is again justified in another categorical imperative:

"A rational being is a member of the realm of ends if he gives universal laws in it while also being subject to those laws. He is sovereign in the realm of ends if, as law-giving, he isn't subject to anyone else's will. A rational being must always regard himself as law-giving in a realm of ends that is possible only through the freedom of the will, and this holds whether he belongs to the realm as a member or as sovereign." ${ }^{36}$

Therefore, it would be ideal if all employees in a company were supported to develop the highest stage of human freedom as personality according to Kant. Good leadership ethics should create a culture of empowerment of autonomous freedom. Ethical legitimate leadership assumes (free from egoism and therefore) autonomous leaders who empower their employees to be autonomous, always in responsibility to the moral law. "...one has both a duty of perfection to oneself and a duty to promote the happiness of others." ${ }^{37}$ The end in itself - objectively understood - of such leadership is the empowerment of men to develop a triple responsibility toward the moral law, himself, and others.

The Kantian approach emphasizes the coexistence of both virtue and institutional ethical considerations. Ethical leadership "must be done from the appropriate moral motive." 38 It needs experienced ethical leaders. A leadership that is only focused on virtue ethically is not complex enough. It needs to be completed by a contextual institutional ethical design of leadership culture, realized in good leaders as well as in good rules and concrete situations, which should protect and encourage the triple responsibility on all hierarchical levels. ${ }^{39}$ The rules should enable the development of this responsibility in the concrete application area to reach the human goal (for instance, by purposeful continued education, flat hierarchies, delegation, cooperative decisions, attitudes of respective employees, etc.).

Economy is in service of humanity. The goal of dualism is not dissolved in ethical discourse - as for example in Ulrich's integrative approach. The intended participative leading is not understood as a kind of consensus democracy. The task of the leader is to find/shape/ balance between the different groups of interest and also

35 Bowie (1999, p.63). Cf. Bruton (2011, p.184).

36 http://www.earlymoderntexts.com/assets/pdfs/kant1785.pdf (p.32).

37 Bowie/Werhane (2005, p.64).

38 Bowie (1999, p.66).

39 Cf. Kuhn/Weibler (2012, p.119). 
to withstand the differences: "We should prefer a theory of leadership that allows a place of disagreement and dissent." 40 Well-founded arguments of profitability and humanity may oppose each other in concrete decisions. These potential differences cannot and should not be argued away or even harmonized. They need to be taken seriously and finally to be decided in terms of lasting humanity. Economic arguments should influence the personal perspective. However, the concept of a divergence of human and profitability goal remains after such reflections. This is the reason why the Kantian leadership ethics demands convincing competence on the part of the leaders and appropriate rules. This competence should help the unconditional personal goal of autonomy to prevail. ${ }^{41}$ If all employees have reached this state of autonomy, there will be no more discussion in case of a conflict. But this is probably utopian.

In summary, Kantian leadership ethics derives humanity in terms of personality and with the idea of responsibility from the categorical imperative - without discourse ethical posits of consensus. The focus is on a strong concept of autonomy which is understood as a guaranteed negative and as empowerment of positive freedom. This approach represents both the virtualethical and the institutional ethical view. The goal of humanity is connected with a strong idea of freedom. This idea does not de-personalize human beings as collective beings. The servant character of profitability connected with this liberal concept of humanity corresponds to the basic values of the social market economy. Therefore, we can call it as LESME. ${ }^{42}$

\section{Metaphysics: servant leadership}

Finally, we take servant leadership into account. This approach is booming especially in the USA and is characterized by Christian ideas. The entrepreneur Robert Greenleaf (1904-1990) designed a vision of a servant attitude of leaders inspired by Herman Hesse's tale Morgenlandfahrt. ${ }^{43}$ The servant leadership idea has gone through a history with some sideways. The main concepts are outlined in this paper.

The required self-conception of the leader as a servant should inspire and empower the employees to be independent and co-responsible. The focus was highly virtue ethics in the beginning. This becomes apparent in the first approaches, for example, in catalogs of abilities and attitudes that good leaders should have.

\footnotetext{
40 Bowie/Werhane (2005, p.147).

41 Cf. Bowie/Werhane (2005, p.147).

42 A relevant analysis of Ulrich's integrative model is to be considered more differentiated because of its discourse ethical orientation.

43 For the following overview, Cf. Hartmann (2013, pp.23-41).
}

Larry Spears listed 10 such abilities, for instance. Evangelical interpretations - such as those of Ken Blanchard and Phil Hodges - are that servant leadership follows the motto: "lead like Jesus." Jesus is an idealized leading figure. Principles and again virtues are stringed together here with intuitive and also occasionally easy references to the bible, for example, "heart, head, hands, and habit." This means that the right motivation, the presence of a vision, or, for instance, the virtues of the pioneer of a visionary performance motivator, etc. ${ }^{44}$

Jennings and Stahl-Wert again outlined the upsidedown pyramid from an evangelical view as follows: 45

1. Run to great purpose: it needs a thrilling vision.

2. Upend the pyramid: it needs the willingness to serve and not to rule.

3. Raise the bar: it is expected that all members of the team want to do their best and expand their range of options.

4. Blaze the trail: the basic condition must be provided.

5. Build the strength: strengths should be strengthened above all and not weaknesses reduced.

The implementation of these five steps raises the (incentives to) motivation, too. A secular version of James Sipe and Don Frick offers a matrix with 21 leading competences that are divided into seven categories. These catalogs may be plausible, but their systematic foundation is missing. Only this foundation would allow plausible ethics starting from the value basis up to the practice fields of leadership. In addition, the questions about an implementation in the concrete leadership culture remain unanswered - even in the practical references of the catalogs. The attempts of Sipe and Frick are the exception as far as the history is concerned.

An ideological Christian value basis to servant leadership presupposes an anthropological and biblical foundation in the image of God in human beings, which is the basis for personal self-reliance and necessarily includes every human being.

It identifies in Jesus Christ a role model of serving without a premature transfer to a concrete leading context or even imposing on individual decision-making situations. "But whoever would be great among you must be your servant" (Mk 10, 43). These words of Jesus (and others) can be transferred into concrete virtues. However, such a transfer is not trivial at all; it needs intensive reflection. What is clear, however, is that serving means not self-denial, but a loving answer to God's offer of

\footnotetext{
44 Cf. ibid (p.32).

45 Cf. Jennings/Stahl-Wert (2003, pp.102 f.), like the reception by Johnson (2009, p.207).
} 
salvation. ${ }^{46}$ By understanding in a Christian way - it frees and empowers servants and those who are served at the same time to freedom on the way to salvation. Those who are served should also be servants themselves.

In the understood service, it is a question of freeing itself critically self-reflexively from self-motivated behavioral automatism, thereby freeing itself internally for the salvation order of God, following Jesus Christ, and then, as a model, enabling others to do likewise. The first question is not: How do I serve? But who do I serve? The Christian answer is: servant leadership is a faithfully implemented life in Christ following the conversion of the threefold love. The first is to serve God, then with Jesus as a model, the human being, the life, and thus also the other, the creation and, finally, the society in common good.

Serving - understood in this way - means freeing oneself critically and self-reflexively from an egoisticdriven behavior. Thus, one becomes free inwardly for God's order of salvation, can follow Jesus Christ, and then empower other people worthy of belief - as a role model to do the same. The first question is not: How do I serve? But Who do I serve ${ }^{47}$ The Christian answer is: servant leadership is a way of life - put into practice - following Jesus to implement the triple commandment of love. First, it is about serving God, then serving one's own life and finally also the community in the common good. ${ }^{48} \mathrm{~A}$ triple Christian responsibility (before God, oneself, and others) is reflected in the fact that cognitive and spiritual aspects are in focus. It is also about being a role model and understanding body and mind as such a consistent unity and about developing this unity; as body, mind, and soul are one unity in the Christian understanding. The responsibility for the body is according to the self-love offered and opposes the fears of Bowie that servant leadership might be in danger of being self-denying or of being used up for others and the company. Such serving as self-enslavement is the opposite of servant leadership. It is the positive view of the impact on others: to encourage personal development to humane salvation means to empower men to develop their creative strengths. Servant leadership is to be understood as a catalyst for personal liberation.

Profitability is not rejected as a goal. The ethical substance of profitability can be interpreted in a religious way: right economizing is the duty for God. ${ }^{49}$ Inefficiency depersonalizes human beings and squanders scarce resources of God's creation. Nevertheless, or rather because of that, the question, "whom the company is serving on the market", needs to be asked.

46 Cf. Hartmann (2013, p.86).

47 Cf. Schnorrenberg (2014, p.349)

48 Cf. ibid; Hartmann (2013, pp.70f, 74).

49 Cf. Brunner (1932, p.384), cited by Hartmann (2013, p.104).
Profitability is not an end in itself, but the duty for God and people..$^{50}$ If profitability should be humanized, then we need companies on the market that are able to do this with economic success. Both goals must be considered. None should be sacrificed for the other. In addition, if they should ever compete with each other, there is no easy answer. We have to keep dualism in mind. But it is obvious that profitability does not mean profit maximization. It is more about expanding free spaces of humanity with economic success (which is obtained humanely). An example is the employment of those who have no chance on the first labor market. Inefficiency which is punished by the market - is to be excluded as well as inhumanity to increase profits.

This means that the two basic goals need to be seen on equal terms. The complexity in the concrete decision remains. There is no easy hierarchy. This requires a high level of professionalism for the leader as a decision responsibility. Servant leadership - justified in a Christian way - takes a biblical-based ideal of a serving culture seriously which is promised by a humane fair efficiency in economic success. The basic idea corresponds to the values of the social market economy. Therefore, it is clearly LESME.

\section{Prospects}

The evaluation of three leadership ethical models illustrated in this paper is only a beginning for both identifying leadership ethics and sounding the relationship with the normative basic ideas of the social market economy out. The future of the model of the social market economy is essentially dependent on the normative basis of the companies' leadership culture. Different ideological approaches are conceivable for this purpose, which has been shown in this paper. If - by contrast - other leadership ethics gained acceptance, the social market economy in terms of the famous identification of changing social culture by Coleman (Coleman bathtub) ${ }^{51}$ would be removed in the medium or long term from practice and led ad absurdum. By seeing like this, it is not an academic glass bead game to ask leadership ethics for their normative content and therefore its compatibility. This distinction is not only intended to initiate a scientific discussion, it also wants to make companies aware of the models of leadership ethics they use to shape their leadership culture. For this, we need a preferably comprehensive evaluation of leadership ethical models. This part in this paper is only the beginning. However, the essential basics of the systematics have been put forward.

50 Cf. Hartmann (2013, p.98).

51 Cf. Coleman (1986). 
Boatright J.R., Does business ethics rest on a mistake? Bus Ethics Q, 9, 583-591, 1999.

Bowie N., A Kantian theory of meaningful work, J Bus Ethics, 17, 1083-1092, 1998.

Bowie N., Business ethics, A Kantian perspective, Oxford, 1999.

Bowie N., Werhane P., Management ethics, Oxford, 2005.

Brunner E., Das Gebot und die Ordnungen. Entwurf einer protestantisch-theologischen Ethik, New York, 1932/1946.

Bruton J., Unternehmensstrategie und Verantwortung. Wie ethisches Handeln Wettbewerbsvorteile schafft, Berlin, 2011.

Ciulla J.B., The importance of leadership in shaping business values, In: Walter C.Z., Richter K., Holzinger M. (Eds.), Corporate ethics and corporate governance, Berlin, Heidelberg, 67-77, 2007.

Coleman J.S., Social theory, social research, and a theory of action, Am J Sociol, 91, 1309-1335, 1986.

Frey D., Nikitopoulus A, Peus C, Weisweiler S., Kastenmüller A., Unternehmenserfolg durch ethikorientierte Unternehmens- und Mitarbeiterführung, In: Meier U., Sill B. (Eds.), Führung, Macht, Sinn, Regensburg, 637-656, 2010.

Friedman M., The social responsibility of business is to increase its profits, In: New York Times Magazine September, 13th 1970, 32-33, 122-126. Reprint in: Walter C., Zimmerli K.R., Holzinger M. (Eds.), Corporate ethics and corporate governance, Berlin, Heidelberg, 173-178, 1970.

Grint K., Leadership, management and command. Rethinking D-Day, New York, 2008.

Hartmann M., Servant leadership in diakonischen Unternehmen, Kohlhammer Verlag, Stuttgart, 2013.

Heifetz R., Leadership without easy answers, Harvard University Press, Cambridge, 1994.

Homann K., Pies I., Wirtschaftsethik in der Moderne: Zur ökonomischen Theorie der Moral, Ethik und Sozialwissenschaften, 5, 3-12, 1994.

Hüster P., Der diakonische Sendungsauftrag: Inkulturation in der Unternehmenskultur kirchlicher Sozialunternehmen, In: Hüster P., Hobelsberger H., Hellwig A. (Eds.), Christliche Organisationskultur prägen. Ansätze im kirchlichen Gesundheitswesen, Freiburg, 9-47, 2016.

Jennings K., Stahl-Wert J., The servant leader. 5 Powerful actions that will transform your team, your business, and your community, Berrett-Koehler Publishers, San Francisco, 2003.
Johnson C.N., Business as mission. A comprehensive guide to theory and practice, InterVarsity Press, Downers Grove, 2009.

Jussen S., Führungsethik - was bringt sie, wer braucht sie? DGFP News, 2009. Available at: http://www.dgfp.de/aktuelles/dgfp-news/fuehrungsethik-was-bringt-sie-wer-braucht-sie-1256 (03/01/2017).

Kant I., Foundations for the metaphysics of morals, 1785. Available at: http://www.earlymoderntexts. com/assets/pdfs/kant1785.pdf (13/09/2017).

Kellermann B., Bad leadership. What it is, how it happens, why it matters, Harvard Business Publishing, Boston, 2004.

Kets de Vries M., Führer N., Hochstapler. Die Psychologie der Führung, Stuttgart, 2009.

Korsgaard C., Creating the kingdom of ends, New York, 1996.

Kuhn T., Weibler J., Führungsethik in Organisationen, Kohlhammer Verlag, Stuttgart, 2012.

Lang R., Rybnikova I., Aktuelle Führungstheorien und Führungskonzepte: "Alter Wein in neuen Schläuchen?", In: Lang R, Rybnikova I. (Eds.), Aktuelle Führungstheorien und Konzepte, Wiesbaden, 15-31, 2014.

MacGregor Burns J., The structure of moral leadership, In: Zimmerli W.C., Richter K., Holzinger M. (Eds.), Corporate ethics and corporate governance, Springer-Verlag, Berlin, Heidelberg, 87-94, 2007.

Malik F., Führen Leisten Leben. Wirksames Management für eine neue Zeit, Frankfurt a.M., 2006

Melé D., Cantón C.G., Human foundations of management. Understanding the Homo Humanus, New York, 2014.

Nass E., Führungsethik Sozialer Marktwirtschaft. Ein Modell zur Identifizierung und Kultivierung von Befähigungsfreiheit, In: Zeitschrift für Marktwirtschaft und Ethik, 5, (forthcoming), 2017

Noll B., Wirtschafts- und Unternehmensethik in der Marktwirtschaft, Stuttgart, 2002.

von der Oelsnitz D., Einführung in die systemische Personalführung, Carl-Auer Verlag, Heidelberg, 2012.

Palazzo G., Organizational integrity - understanding the dimensiions of ethical and unethical behavior in corporations, In: Zimmerli W.C., Richter K., Holzinger M. (Eds.), Corporate Ethics and Corporate Governance, Berlin, Heidelberg, 113-128, 2007. 
Pies I., Beckmann M., Hielscher S., Was müssen Führungskräfte können? Zur ordonomischen Vermittlung strategischer Kompetenzen für Manager, Z Betriebswirtsch, 81, 15-38, 2011.

Pies I., Beckmann M., Hielscher S., Nachhaltigkeit durch New Governance: Ein ordonomisches Konzept für strategisches Management, Die Betriebswirtsch, 72, 325-341, 2012.

Rohrhirsch F., Christliche Führung - Anspruch und Wirklichkeit. Führen mit Persönlichkeit und Ethik, Berlin, 2013.

Schein E.H., Organisationskultur, Bergisch Gladbach, 2003.

Schnorrenberg L.J., Wesen D., Dienender Führung" auf der Spur, In: Schnorrenberg L.J., Stahl H.K., Hinterhuber H.H., Pircher-Friedrich A.M. (Eds.), Servant Leadership. Prinzipien dienender Führung in Unternehmen, 2th ed., Berlin, 345-350, 2014.
Schwartz M.S., Ethical decision-making theory: an integrated approach, J Bus Ethics, 139, 755-776, 2016.

Sims R.R., Brinkmann J., Enron ethics (or: why culture matters more than codes), J Bus Ethics, 45, 243256, 2003.

Thielemann U., Ulrich P., Standards guter Unternehmensführung. Zwölf internationale Initiativen und ihr normativer Orientierungsgehalt. St. Galler Beiträge zur Wirtschaftsethik, 43, Bern, 2009.

Ulrich P., Führungsethik, In: Korff W., Baumgartner A., Franz H., Genosko J., Homann K., Kirchner C., Kluxen W., Küpper H.-U., Picot A., Rendtorff T., Richter R., Sautter H., Schlecht O (Eds.), Handbuch der Wirtschaftsethik, Bd. 4: Ausgewählte Handlungsfelder, Gütersloh, 230-248, 1999. 
